\title{
サクションアンカー周辺地盤の応答特性 \\ Dynamic Response of Seabed Around Suction Anchor
}

\author{
高谷 富也*、前野 賀彦 $* *$ 、平石 哲也 $* * *$ 、高山 知司 $* * *$ \\ Tomiya.Takatani, Yoshi-hiko.Maeno, \\ Tetsuya.Hiraishi and Tomotsuka.Takayama
}

\begin{abstract}
The frequency response of seabed around a suction anchor subjected to a mooring force of floating structure is numerically evaluated by taking the seabed characteristics into consideration. The seabed is assumed to be a fluid-saturated poroelastic medium whose behavior is governed by Biot's theory of wave propagation, and the suction anchor is modeled as a rigid and hollow cylinder with upper cover. The suction force acts on the surface of upper cover in suction anchor. The effect of the skirt length and of suction anchor on the response of seabed around it is investigated.

Key words: Suction Anchor, Mooring Force, Poroelastic seabed, Frequency Response of seabed
\end{abstract}

1.はじめに

沿岸域の開発に伴い海岸構造物の設置水域は、より 水深の大きい沖へ、また岩盤基礎の得られにくい場所 へと展開することになるものと考えられる。それらの 海岸構造物の構造の一つとして浮体構造を考える場合 には、その係留が重要な問題となる。そこで、高谷ら (1991) は支圧型アンカーの軟弱地盤への適用を考え、 定常風を受ける係留船舶の振れ回りによる支圧型アン カー周辺地盤の応答を解析し検討している。その後、 高谷ら $(1992 \cdot a)$ は緊張係留方式の採用による船舶の 振れ回りにより係留索に生じる衝撃張力の緩和効果を 検証した。また、前野ら $(1993 \cdot a)$ は、振れ回りを許 容しない多点係留への適用を考えて、支圧型アンカー 周辺地盤の応答特性を検討した。著者らの一連の研究 により、支圧型アンカーの軟弱地盤への適用の有効性 を示したが、解決されるべき問題点として支圧型アン カーの施工法が指摘された。そこで、前野ら (1993・b ) は施工性のよさから大気圧を把駐力として取り込む サクションアンカーの軟弱地盤への適用を考え、その 適用性を検討した。その結果によれば、アンカーの変 位の周波数応答は、アンカーの直径、スカートの長さ およびサクションの大きさに強く依存することが明か となった。しかしながら、実際問題への適応を考える ときには、アンカー周辺地盤の支持力に関する検証が 必要である。そこで、本研究ではサクションアンカー 内部を含む周辺地盤内部の変位 - 応力および間隙水圧 の発達特性に関して解析を行った。

\section{2. 解析手法}

サクションアンカーは、上端が閉じられた中空の鋼 管からなり、上端からの排水を認めることにより静水 圧を利用して設置され、設置後上端を完全に閉じるか 排水を継続することにより大気圧を把駐力に取り組む ものである。図ー1は、海洋におけるサクションアン

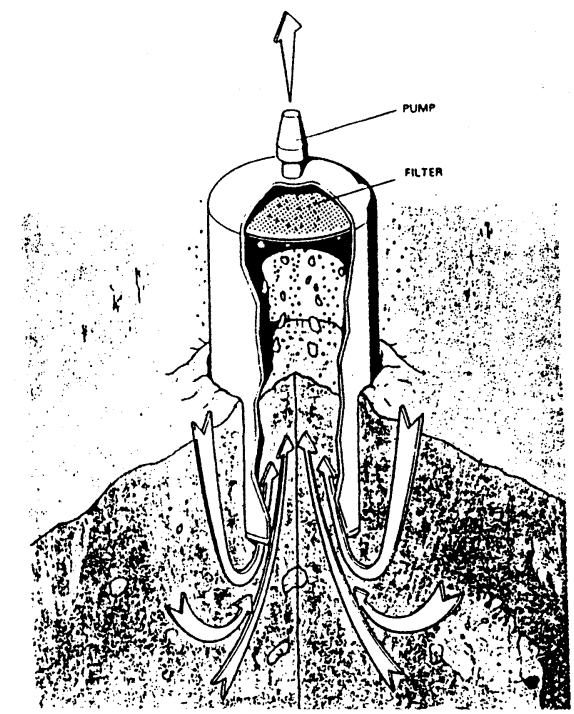

図ー1 サクションアンカー(Hogervorst, 1980)

カーの設置の模式図を示 したものである。著者ら (1993)は、図一1に見ら れる海底地盤表面付近に 設置されるサクションア ンカーのモデル化に際し て図ー2に見られるよう に上端が閉じられた中空 の鋼管を想定し、サクシ ヨンアンカーを(等分布 加振力十㓮丹筒） からなる

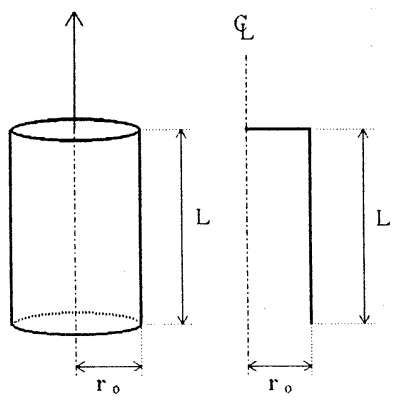

図一 2 円筒状構造物

構造物と見なし、サクションアンカー変位および周辺地盤の応
* 正会員 舞鶴工業高等専門学校

** 正会員

*** 正会員
日本大学短期大学部

運輸省港湾技術研究所
建設システム工学科（テ625 京都府舞鶴市白屋234番地）

建設学科

水工部 
答特性を求める。このモデル化においては、サクショ ンを等分布加振力として、サクションアンカーの上端 部分に作用させ、円筒部分を剛円筒構造物と考えて解 析を行うものである。また、サクションアンカーが設 置される海底地盤として、Biot (1956)が提案してい る土粒子骨格と間隙水の二相系から構成される多孔質 飽和弾性地盤を仮定している。

サクションアンカーの上端部分に作用するサクショ ンおよび用円筒部分を考慮したサクションアンカー変 位および周辺地盤の変位は、次式に示される円形面上 に作用する等分布加振力による変位解 $u_{z}$ および円周上 に作用するリング状分布加振力による変位解 $u_{z}$ を用い て評価を行うことができる。

(等分布加振力による変位解)

$$
u_{z}=-\frac{Q_{z}}{2 \pi \mu r_{0}} \int_{0}^{\infty} \frac{U(\kappa)}{\beta_{3} \Theta F(\kappa)} J_{1}\left(\kappa r_{0}\right) J_{0}(\kappa r) d \kappa \cdots \cdots \cdots
$$

(リング状分布加振力による変位解)

$$
u_{z}=-\frac{q_{z} r_{0}}{2 \mu} \int_{0}^{\infty} \frac{\kappa U(\kappa)}{\beta_{3} \Theta F(\kappa)} J_{0}\left(\kappa r_{0}\right) J_{0}(\kappa r) d \kappa \cdots \cdots \cdots
$$

ここに、 $Q_{z}$ は等分布加振力の合力、 $q_{z}$ はリング状分布 加振力の荷重振幅、 $r_{0}$ は載荷面の半径、 $r=\sqrt{x^{2}+y^{2}}$ 、 $\kappa$ は波数、 $\mu$ は多孔質飽和弾性体のせん断弾性係数、 $J_{0}(), J_{1}()$ はそれぞれ第 0 次および第 1 次のベッセル 関数である。また、 $\beta_{3}, \Theta, U(\kappa), F(\kappa)$ は波数 $\kappa$ の関数 である（高谷・北村, 1990）。

いま、図一 3 に示 すように剛円筒部分 を有限個のリング要 素に分割し、各要素 内でのリング状分布 加振力を一定とし、 影響係数の概念を用 いて全要素の等分布 リング状加振力によ る変位を重ね合わせ る。また、等分布加 振力が作用するサク ションアンカー上面 中央の変位および各

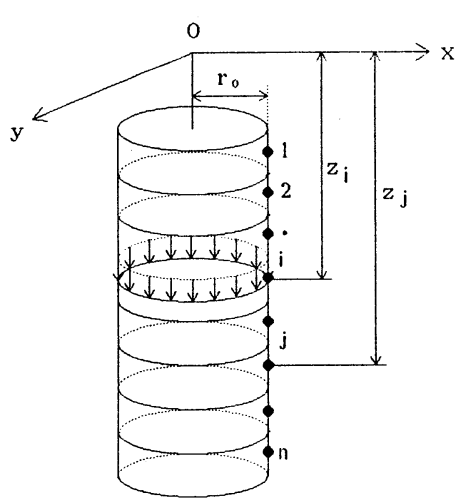

図-3 円筒部分の分割
リング要素の地盤骨格の変位が等しいという条件のも とで、サクションアンカー上面に作用する鉛直等分布 加振力および各リング要素に作用する等分布加振力 $q_{z}$ を末知とする連立一次方程式が得られる。連立一次方 程式を解いて得られる未知等分布加振力およびリング 状分布加振力の合力がサクションアンカーに作用する 全加振外力に等しいという条件を用いれば、サクショ ンアンカーを（等分布加振力十剛円筒）なる構造物に モデル化した場合のアンカー変位を求めることができ る（前野ら，1993）。

また、サクションアンカー周辺地盤における変位・ 応力および間隙水圧については、次式に示すように上 述した解析方法によりサクションアンカー変位を求め

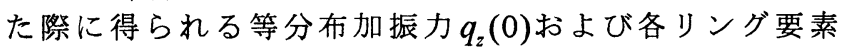

( $\mathrm{i}$ 番目) に作用するリング状分布加振力 $q_{z}(i)$ にる
変位・応力解を用いて容易に得ることができる。

$$
v=G(r, z \mid 0) q_{z}(0)+\sum_{i=1}^{N} G_{i}(r, z \mid i) q_{z}(i) \cdots \cdots \cdots
$$

ここに、vはサクションアンカー周辺地盤における変 位・応力および間隙水圧であり、 $G(r, z \mid 0), G_{i}(r, z \mid i)$ は それぞれサクションアンカー上面に作用する等分布加 振力および円筒部分の $\mathrm{i}$ 番目の要素による $(r, z)$ なる 位置の変位・応力および間隙水圧の影響係数である。 また、 $N$ は円筒部分における分割数である。なお、态 力解および間隙水圧の詳細については、高谷ら(1992 •b) の論文に譲る。

\section{3.アンカー周辺地盤の応答について}

本研究では、サクションアンカーが設置される海底 地盤の条件として、以下に示すような飽和砂質土に対 する諸弹性定数および密度等の数值 ( Halpern・Christi ano, 1986) を用いて、サクションアンカーの変位およ び周辺地盤の変位・応力および間隙水圧の周波数応答 を求める。

$$
\begin{aligned}
& \mu=96 \mathrm{MPa}, \lambda=432 \mathrm{MPa}, \quad Q=280 \mathrm{MPa}, \\
& R=274 \mathrm{MPa}, \quad v=0.3 \quad(\text { ポアソン比) } \\
& f=0.48 \quad \text { (多孔質飽和弾性地盤の間隙率) } \\
& \rho_{s}=2.67 \mathrm{~g} / \mathrm{cm}^{3} \quad \text { (弾性骨格の密度) } \\
& \rho_{f}=1.00 \mathrm{~g} / \mathrm{cm}^{3} \quad \text { (間隙水の密度) }
\end{aligned}
$$

ここに、Qは弾性骨格と間隙水の体積変化の間に起こ る相互作用に関する連成係数、 $R$ は間隙水の圧縮剛性 に関係する係数である。また、上記の $\rho_{s}, \rho_{f}$ は素材 としての密度である。また、本研究では無次元加振振 動 数 $a_{0}\left(=\omega r_{0} / V s\right)$ お よ゙無次元透水係数 $K_{0}\left(=k V s / g r_{0}\right)$ の 2 つパラメータを用いて、サクシ ヨンアンカーおよび周辺地盤の応答特性について調べ る。なお、上記の無次元パラメータ中に見られる $r_{0}$ は サクションアンカーの半径、 $k$ は地盤の透水係数、 $g$ は重力の加速度、 $\omega$ は円振動数、Vs は素材における 横波の伝播速度である。また、本研究では、地盤の透 水係数として $k=10^{-1} \sim 10^{-5} \mathrm{~m} / \mathrm{s}$ の範囲を考えているた めに、無次元透水倸数 $K_{0}$ は $10 \sim 10^{-3}$ なる範囲の值を 仮定する。

(1) サクションアンカーの変位応答

図一 4 6 はそれぞれ無次元透水係数 $K_{0}=10.0,0.1$, 0.001 のつの場合について、スカート長 $L / r_{0}=10.0$ ( $L$ : スカート長)におけるサクションアンカーの変位 応答を、サクションアンカーの円筒部分の全周面摩擦 力に対するサクションの比 $P_{0}$ をパラメータにして図示 したものである。なお、 $P_{0}$ が大きくなることは、サク ションが大きくなることを意味している。また、図中 のRe［］およびIm［］はそれぞれ実部および虚部を 取ることを意味する。これらの図より、 $P_{0}$ が大きくな るにつれてサクションアンカーの変位は小さくなって いる。また、サクションアンカーに作用する加振外力 の振動数が高くなるにつれて、サクションアンカー変 位の実部が急激に減少している。一方、変位の虚部は $\omega r_{0} / V s=0.3$ をピークとして緩やかな減少傾向にある 
ことがわかる。したがって、サクションアンカー変位 の絶対值としては、いずれの無次元透水係数において も無次元加振振動数 $\omega r_{0} / V s=0.3$ 付近に変曲点を有す るものとなっていることがわかる。また、無次元透水 係数 $K_{0}$ が小さくなれば、サクションアンカー変位も 小さくなっている。これは、 $K_{0}$ が小さくなることは 液体の粘性による減衰が大きくなることを意味してお り、これによるアンカー変位は小さくなっている。

図一 7 は無次元透水係数 $K_{0}=0.1$ の場合について、
サクションアンカーの円筒部分の全周面摩擦力に対す るサクションの比 $P_{0}=1.0$ におけるサクションアンカー の変位応答を、スカート長 $L / r_{0}$ をパラメータにして 図示したものである。この図より、スカート長が長く なるにつれてサクションアンカーの円筒部分の周面摩 擦力が大きくなるため、サクションアンカーの変位は 小さくなっている。また、サクションアンカー変位の 実部は、無次元加振振動数が大きくなるにつれて、減 少しているが、虚部にはピークが見られ、このピーク

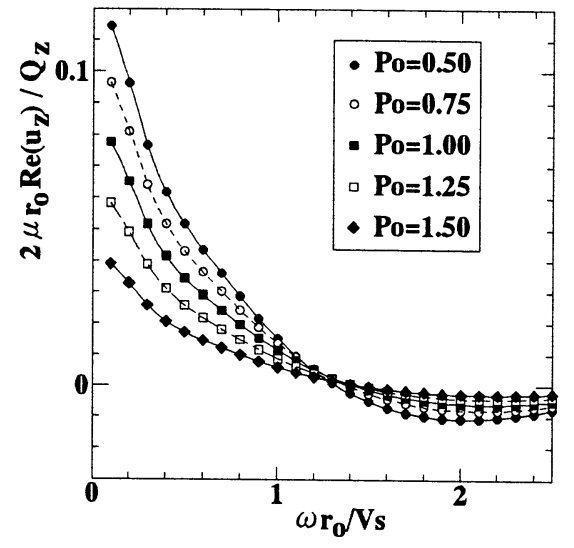

(a) 実

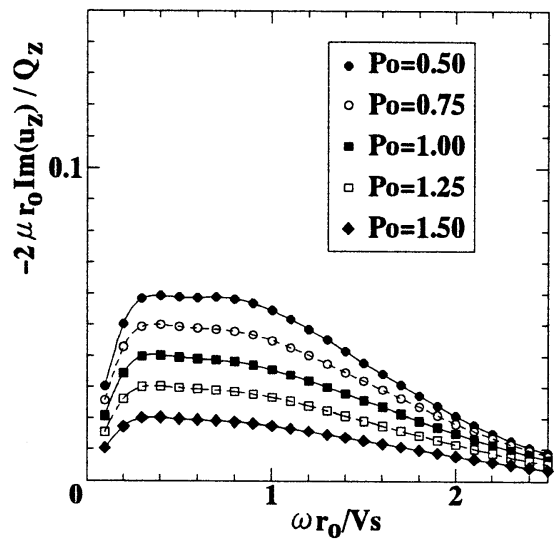

(b) 虚 部

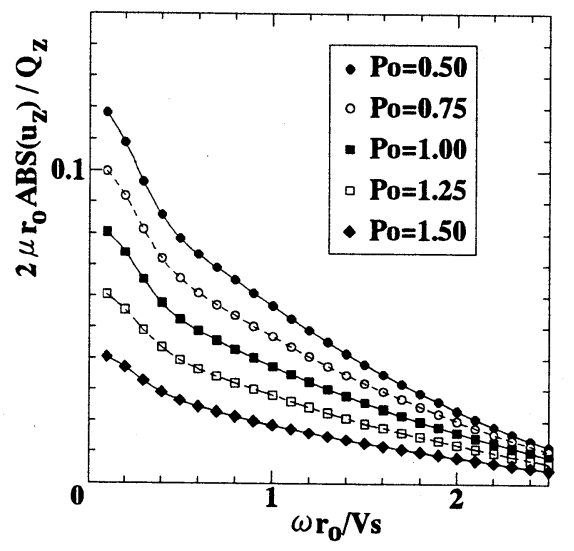

(c) 絶 対 值

図ー4 サクションアンカーの変位応答 $\left(K_{0}=10.0, L / r_{0}=10.0\right)$

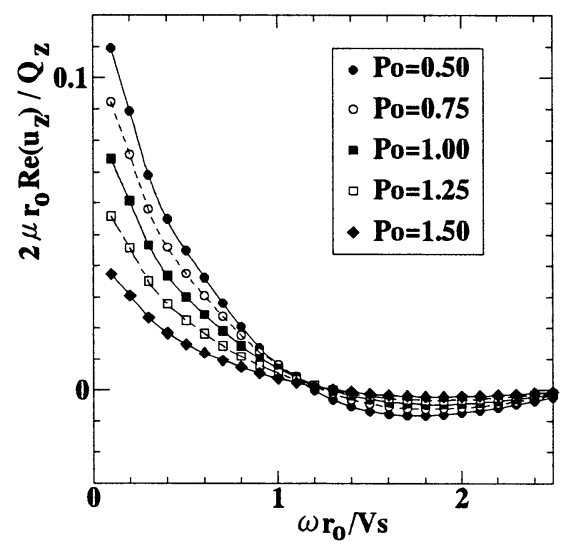

(a) 実 部

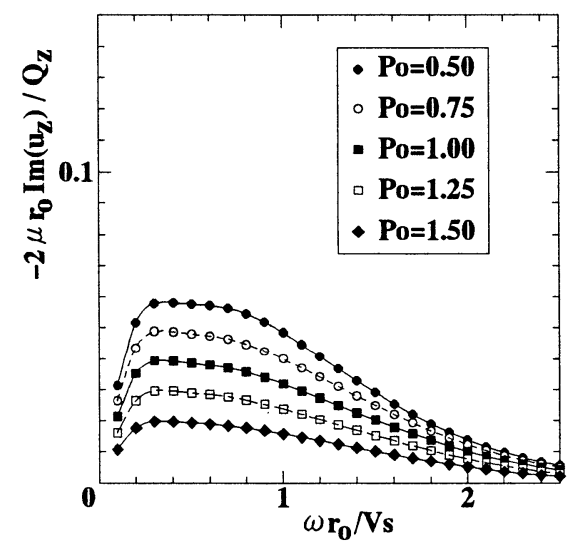

(b) 虚 部

図-5 サクションアンカーの変位応答 $\left(K_{0}=0.1, L / r_{0}=10.0\right)$

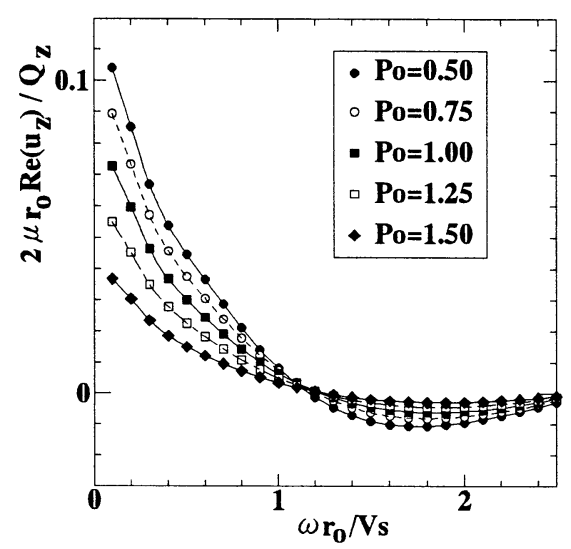

(a) 実 部

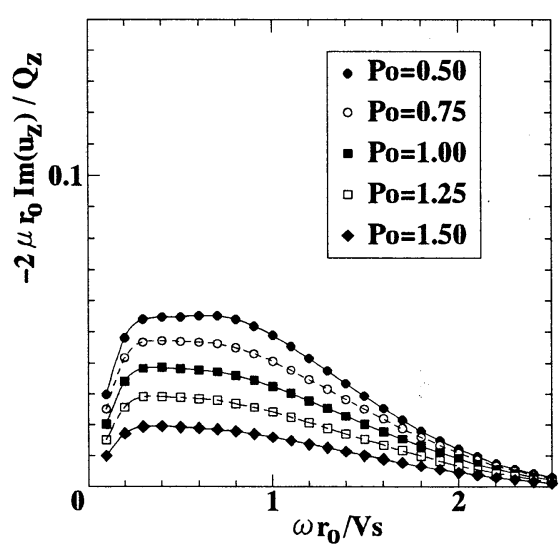

(b) 虚 部

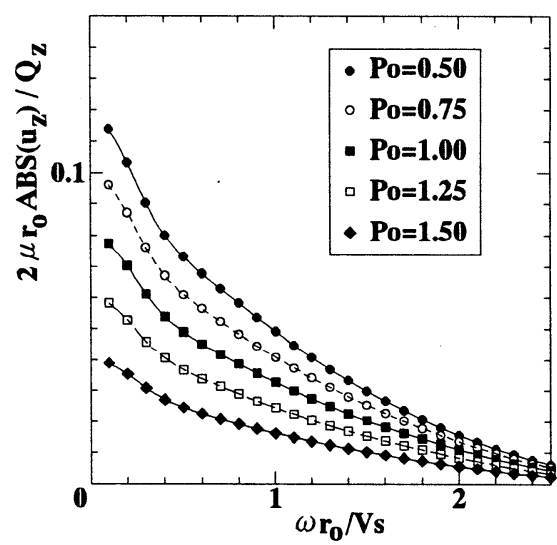

(c) 絶 対 值

図-6 サクションアンカーの変位态答 $\left(K_{0}-0.001, L / r_{0}-10.0\right)$ 


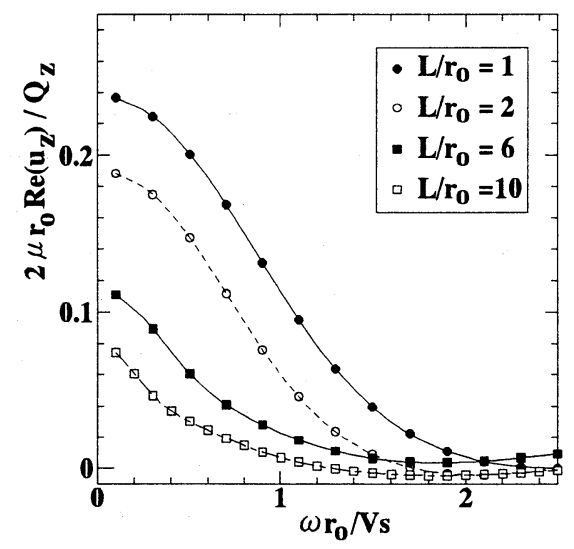

(a) 実

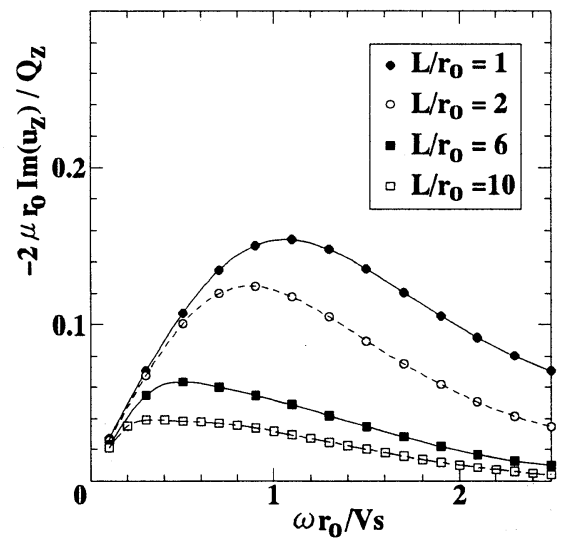

(b) 虚

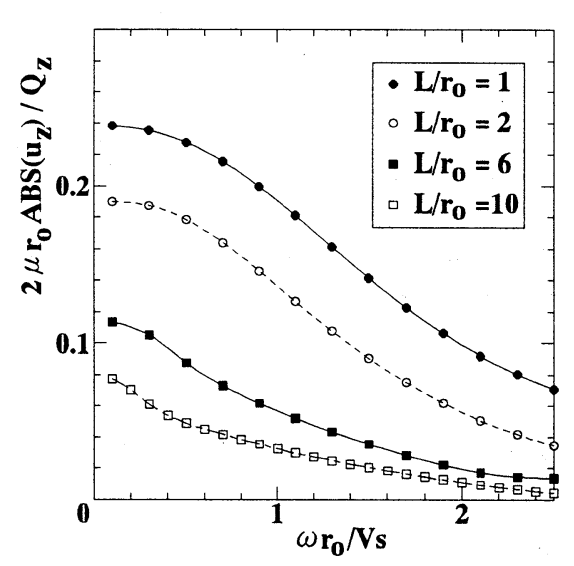

(c) 絶 対 值

図ー7 スカート長とアンカー変位の関係 $\left(K_{0}=0.1, P_{0}=1.0\right)$

はスカート長が長くなるにつれて低振動数域へと移行 していることがわかる。これは、スカート長が長くな れば、サクションアンカーから周辺地盤への逸散減衰 効果が小さくなることを示している。

\section{（2）アンカー周辺地盤の変位応答}

図一 8 は無次元透水係数 $K_{0}=0.1$ の場合について、 サクションアンカーの円筒部分の全周面摩擦力に対す るサクションの比 $P_{0}=1.0$ およびスカート長 $L / r_{0}=6.0$ におけるサクションアンカー周辺地盤の鉛直変位の実 部および虚部を図示したものである。なお、無次元加 振振動数 $\omega r_{0} / V s$ として $0.5,1.0,1.5,2.0,2.5$ の 5 つのケースについて求めたものである。また、サクシ ヨンアンカー周辺地盤の変位は、半径方向 $3 r_{0}$ と深さ 方向 $10 r_{0}$ の範囲を図示しており、メッシュのサイズは $\mathrm{x}$ 方向および $\mathrm{z}$ 方向はそれぞれ $0.25 r_{0}$ および $0.5 r_{0}$ で ある。したがって、アンカーのスカート長が $L / r_{0}=6.0$ であるため、図中においてx 方向へ 4 メッ シュ幅および $\mathrm{z}$ 方向へ 12 メッシュ幅分がサクションア ンカー内部の変位となる。この図より、アンカー周辺 地盤の変位の実部は、無次元加振振動数が大きくなる につれて、サクションアンカーからの波動が周辺地盤 一伝播している様子がわかる。とくに、無次元加振振 動数が大きくなれば、サクションアンカー外側近傍の 地盤のみが振動しており、深さ方向への波動の伝播範 囲は水平方向へのそれに比べて小さいことがわかる。 これは、サクションアンカーが海底地盤表面に設置さ れていることで、水平方向へのアンカーからの波動の 伝播は、深さ方向に比べて地盤による拘束が少ないこ とによるものと考えられる。また、サクションアンカ 一内部の地盤については、加振振動数が低い場合には アンカー変位とほぼ同じ程度の值となっている。した がって、サクションアンカー内部の地盤は加振振動数 が低い場合にはアンカーと同じ運動をしているが、振 動数が高くなるにつれてサクションアンカーとは異な る運動をすることがわかる。

一方、サクションアンカー周辺地盤の変位の虚部に ついては、無次元加振振動数が大きくなるにつれてア ンカーからの逸散減衰効果が小さくなっていることが わかる。また、変位の実部において見られたように、 減衰効果はアンカーの深さ方向に比べて水平方向が大
きくなっている。これも地盤の拘束力による影響が現 れているものと考えられる。

\section{（3）アンカー周辺地盤の間陌水圧応答}

図 -9 は無次元透水係数 $K_{0}=0.1$ の場合について、 サクションの比 $P_{0}=1.0$ およびスカート長 $L / r_{0}=6.0$ に おけるサクションアンカー内部の間隙水圧の周波数応 答を示したものである。なお、間隙水圧の応答を調心゙ ている所は、 $\left(r / r_{0}, z / r_{0}\right)=(0.0,0.0),(0.0,2.0),(0.0,4.0)$ の 3 地点である。この図より明らかなように、サクシ ヨンが作用している $\left(r / r_{0}, z / r_{0}\right)=(0.0,0.0)$ の位置、す なわちサクションアンカー上端部分における間隙水圧 の応答は、加振振動数が高くなるにつれて大きくなっ ているが、サクションアンカー上端部分から離れるに つれて急激に間隙水圧の忘答值は小さくなっているこ とがわかる。これは、サクションアンカー上端部分に 作用するサクションによる間隙水圧への影響範囲がア ンカー半径の1倍程度であることによるものと推察さ れる。このことより、サクションアンカーの円筒部分 の全周面摩擦力に対するサクションの比 $P_{0}$ が大きくな れば、サクションによる間隙水圧への影響範囲も大き くなるものと思われる。

次に、上述した地点における間隙水圧の周波数応答 を用いて、サクションアンカーに係留力が作用した場 合の時刻歴応答を検討する。図ー10は平石ら (1991) が行った船首一点ブイ係留方式で係留された船舶の係 留実験で得られた風速 $50 \mathrm{~m} / \mathrm{s}$ 時の避泊ブイ下のアンカ ーチェーン張力の時刻歴変動を示したものである。

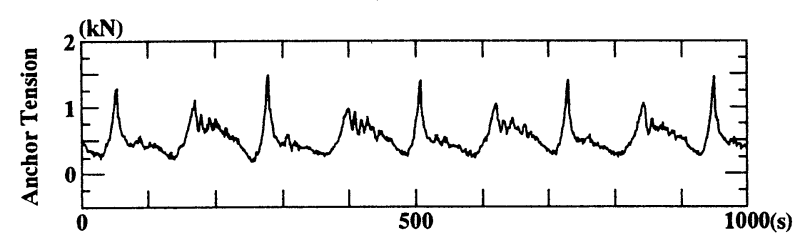

図-10 係留鎖張力の時刻歴変動

図ー11 は、図ー10に示すアンカーチェーン張力が サクションアンカーに作用した場合のアンカー内部に おける 3 地点（図 -9 参照）での間隙水圧の応答を求 めたものである。この図より、サクションが作用して いる $\left(r / r_{0}, z / r_{0}\right)=(0.0,0.0)$ の位置、すなわちサクショ 


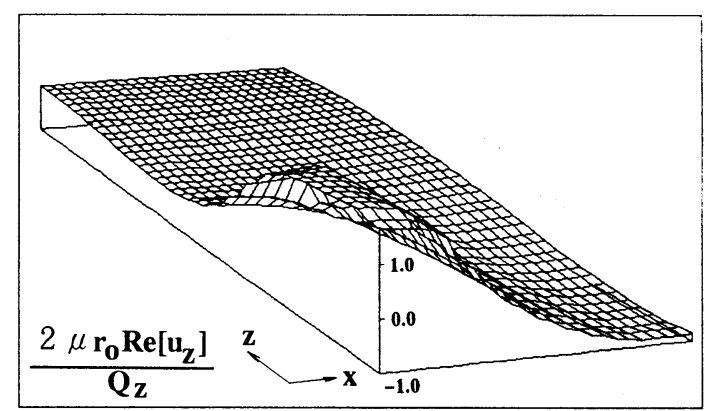

(a) $\omega r_{0} / V s=0.5$

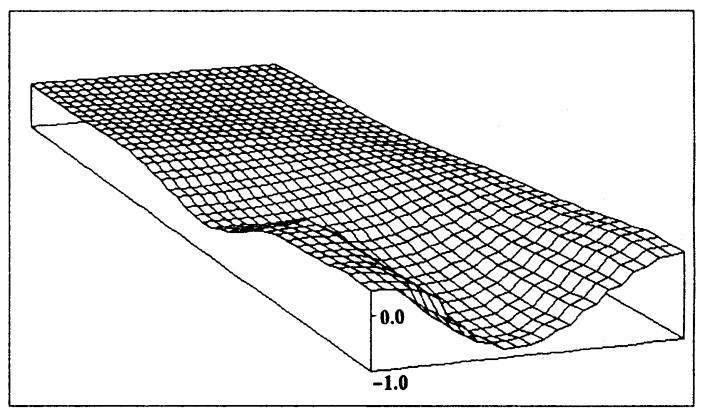

(b) $\omega r_{0} / V s=1.0$

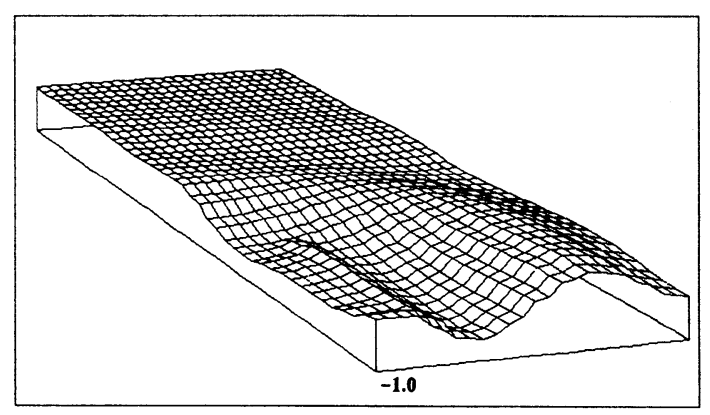

(c) $\omega r_{0} / V s=1.5$

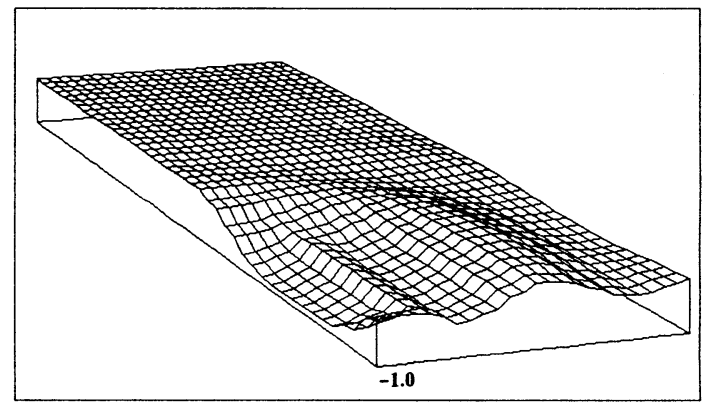

(d) $\omega r_{0} / V s=2.0$

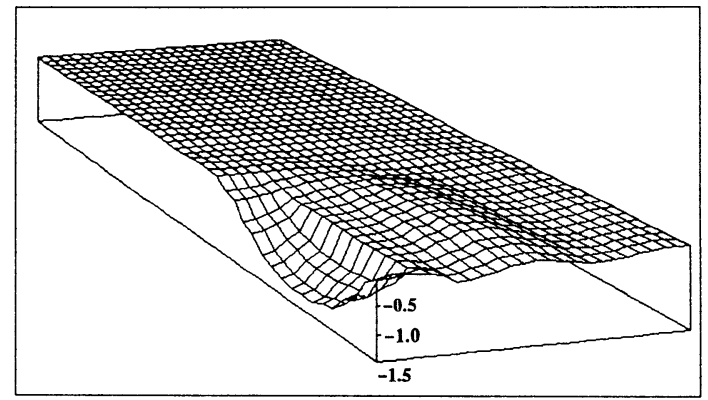

(e) $\omega r_{0} / V s=2.5$

図ー8 サクションアンカー周辺地盤の変位分布 $\left(K_{0}=0.1, L / r_{0}=6.0, P_{0}=1.0, \quad x / r_{0}=0 \sim 6, \quad z / r_{0}=0 \sim 10\right)$ (a) $\omega r_{0} / V s=0.5$

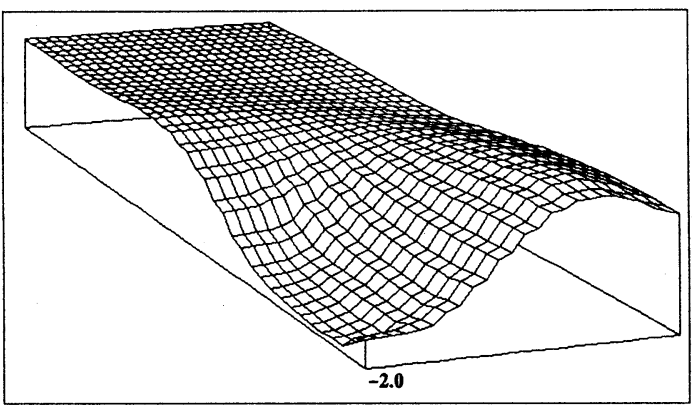

(b) $\omega r_{0} / V s=1.0$

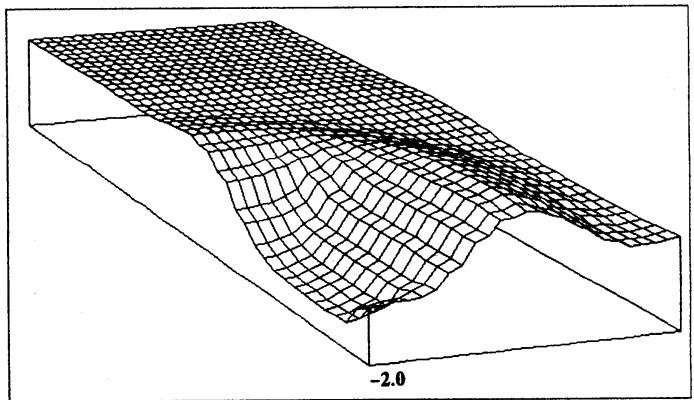

(c) $\omega r_{0} / V s=1.5$

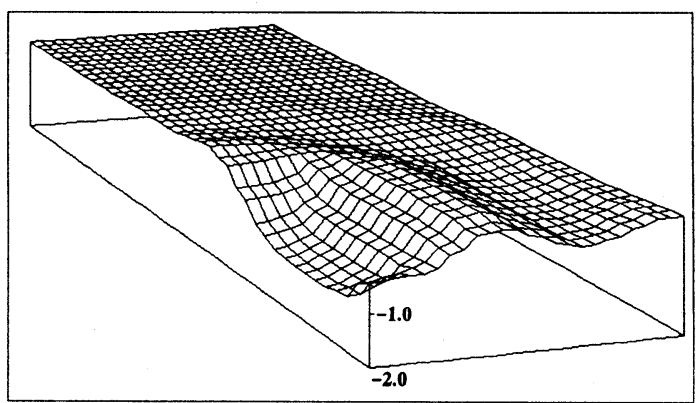

(d) $\omega r_{0} / V s=2.0$

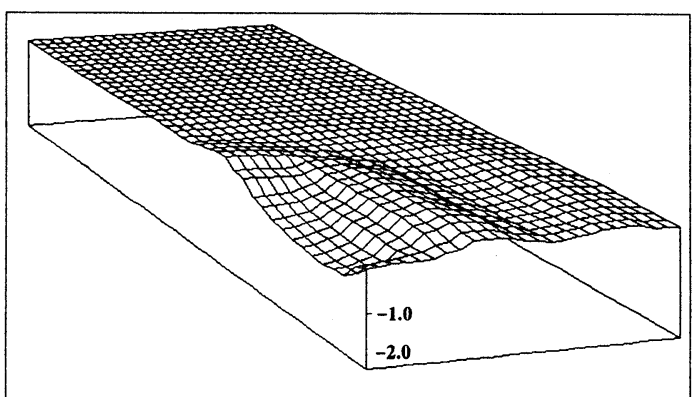

(e) $\omega r_{0} / V s=2.5$

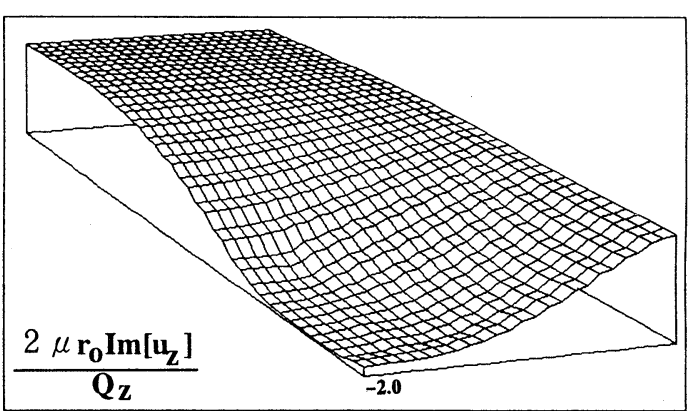




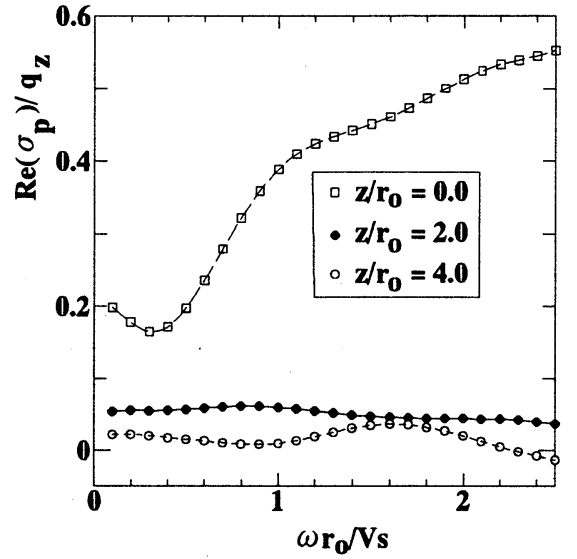

(a) 実 部

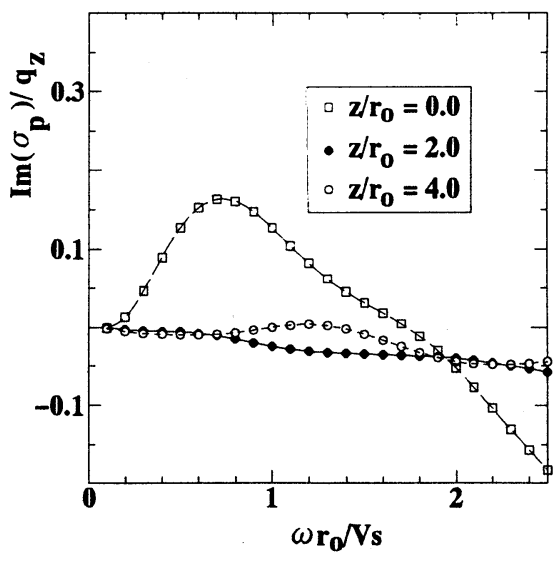

（b）虚 部

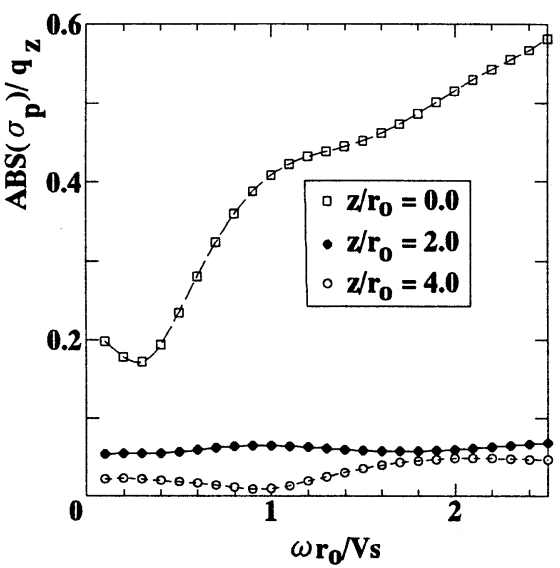

(c) 絶 対 值

図一 9 サクションアンカー内部における間隙水圧の周波数応答 $\left(K_{0}=0.1, L / r_{0}=6.0, P_{0}=1.0\right)$

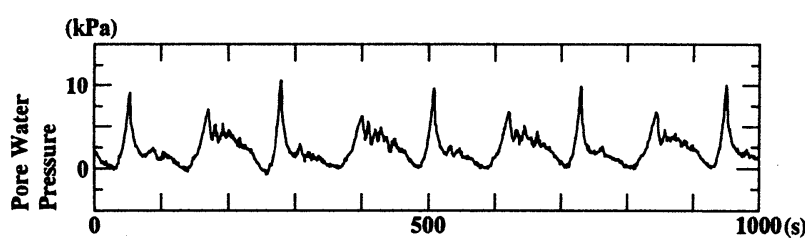

(a) $\left(r / r_{0}, z / r_{0}\right)=(0.0,0.0)$

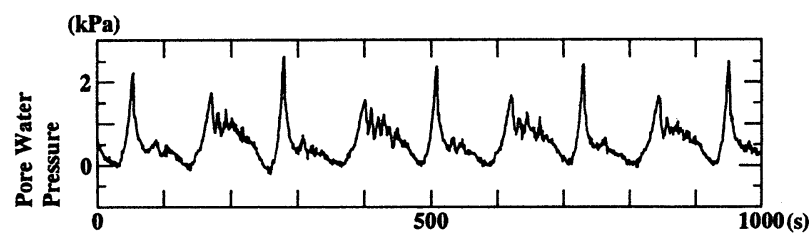

(b) $\left(r / r_{0}, z / r_{0}\right)=(0.0,2.0)$

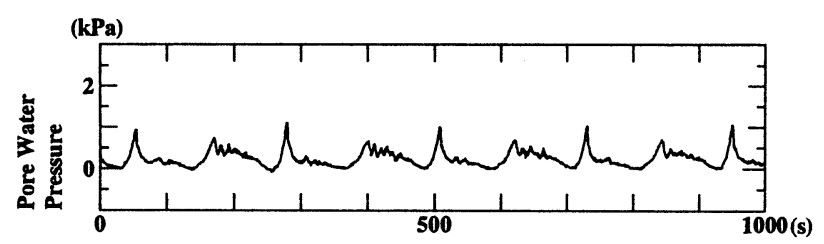

(c) $\left(r / r_{0}, z / r_{0}\right)=(0.0,4.0)$

図 -10 間隙水圧の時刻歴応答

$\left(K_{0}=0.1, L / r_{0}=6.0, P_{0}=1.0\right)$

ンアンカー上端部分における間隙水圧の応答が極めて 大きなものとなっていることがわかる。また、それぞ れの地点での応答值は、図ー9に示される間隙水圧の 周波数応答に係留索張力の振動数特性が加わったもの となるため、単純に周波数応答から時刻歴応答值を推 定することはできない。また、これらのことより、サ クションの比 $P_{0}$ が大きくなれば、さらにこの地点にお ける間隙水圧の応答は大きくなるものと考えられる。

\section{4.おわりに}

本研究は、浮体構造物の係留用アンカーとして、施 工性のよさから大気圧を把駐力として取り込むサクシ ヨンアンカーの軟弱地盤への適用を考え、サクション アンカー内部を含む周辺地盤内の変位 · 応力および間 隙水圧の発達特性に関する検討を行った。その結果、 サクションアンカー周辺地盤における変位・応力およ
び間隙水圧の応答特性は、海底地盤の透水性、サクシ ヨンアンカーのスカート長およびサクションカに大き く依存する。とくに、サクションアンカー内部におけ る間隙水圧は、サクションカの違いに大きく影響され る。しかしながら、サクションカが作用するサクショ ンアンカー上端部分から離れるにつれて、間隙水圧の 応答值は急激に減少する。このため、サクションアン カー上端部分に作用するサクションカと間隙水圧の影 響範囲に何らかの密接な関係があるものと思われる。 したがって、サクションアンカーの安定性を把握する には、これらの関係をより詳細に検討する必要があろ う。また、本研究で得られた結果より、サクションア ンカーの実用化に際しては、サクションアンカー周辺 地盤の支持力に関するより詳細な応答解析および実験 等を通じて、サクションカと間隙水圧の影響範囲に関 する詳細な資料の積み重ねが必要になるものと思われ るが、これらは今後の課題と言えよう。

\section{参考文献}

高谷富也・前野賀彦・高山知司・平石哲也（1991）：定常風を 受ける係留船舶の振れ回りによるアンカー周边地盤の応 答、海岸工学論文集、第 38 巻、pp.736-740.

高谷富也 - 前野賀彦 - 平石哲也 - 高山知司 $(1992 \cdot a)$ ：船舶 の振れ回りによる緊張係留アンカー周辺地盤の応答、海 岸工学論文集、第 39 巻、pp. 846-850.

高谷富也・前野賀彦・平石哲也・高山知司 $(1992 \cdot b)$ 定常係 留力を受けるアンカー周辺地盤の周波数応答特性につい て、海洋開発論文集、Vol. 8、pp.451-456.

平石哲也・本城 智・古川正美(1991)：避泊フェリーの係留 張力と振れ回り運動、海岸工学論文集、第 38 巻、pp. $731-735$.

前野賀彦・高谷富也 - 平石哲也 - 高山知司 $(1993 \cdot a) ： 2$ 点 係留された船舶の倸留アンカー周辺地盤の応答、海洋開 発論文集、Vo1.9、pp. 123-128.

前野賀彦・高谷富也 - 平石哲也 - 高山知司 $(1993 \cdot b)$ : 浮体 係留へのサクションアンカーの適用について、海岸工学 論文集、第40巻、pp.906-910.

Biot, M.A.(1956): Theory of Propagation of Elastic Waves in a Fluid-Saturated Porous Solid, J. Acoust. Soci. America, Vol.2, pp.168-178.

Halpern, M.R. and Christiano, P. (1986): Response of Poroelastic Half-Space to Steady-State Harmonic Surface Tractions, Int. J. Numer. Anal. Methods Geomech., Vol.10, pp.606-632.

Hogervorst, J.R. (1980): Field Trails with Large Diameter Suction Anchor, Offshore Technology Conference, pp.217-224. 